a) Institute of Economics of the Committee of Science of the Ministry of Education and Science of the Republic of Kazakhstan

b) New Economic University named after T. Ryskulov, Almaty

\title{
INNOVATIVE DEVELOPMENT OF KAZAKHSTAN ON THE BASIS OF TRIPLE HELIX AND CLUSTER APPROACH ${ }^{1}$
}

The aim of the research is to study the Triple Helix model feasibility in developing innovations and using cluster approach in Kazakhstan. There are possible points of the emergence of clusters in Kazakhstan. However, there are a lot of constraining factors. First of all, institutional and social factors: the culture of business, unfair competition, low trust of economic agents to each other and to power institutes, low psychological readiness for cooperation of the enterprises of various branches and regions, poor development of chambers of commerce, and industrial associations. For the time being, the majority of regions of Kazakhstan are characterized by a limited set of high technology industrial branches, and a sharp shortage of universities generating innovation and research institutes. The research results show that the open innovation model is realized in a limited scale that does not allow to export innovations into external markets, to participate in global technology chains and international research networks. At the same time, some interaction schemes and preconditions for the development of the Triple Helix model are emerging. However, in general, the innovation policy is not systemic; it does not unite actions in the sphere of science and technology, education, industry, and regional initiatives. As the result of the research, some policy implications are given. For the development of clusters in Kazakhstan, it is desirable to use such a way, as integration into global cluster networks. It is necessary to make use of foreign experience at which various specialized state agencies become participants of clusters. It is necessary to focus not only on science but also industry, which should play the central role in the innovation process.

Keywords: cluster, triple helix model, innovation, technology, science, industry, development

\section{Introduction}

Nowadays, innovations have been announced as an important priority of economic policy in

${ }^{1}$ C Dnishev F. M., Alzhanova F. G., Alibekova G. Zh. Text. 2015.
Kazakhstan. This finds support in national strategies and programs, and current practical measures.

In 2005 году the Program on formation and development of the national innovation system in 2005-2015 is proved (in 2010 it was substituted by the State program of forced industrial - innovative development). The patent legislation has 
Table 1

Development of National Innovation System of Kazakhstan

\begin{tabular}{|c|c|c|c|}
\hline & 2003-2009 & 2010-2014 & 2015-2019 \\
\hline 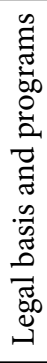 & $\begin{array}{l}\text { Law "About state support of } \\
\text { innovation activity" } \\
\text { The first strategy for industrial- } \\
\text { innovation development until } \\
2015 \\
\text { Program on the establishment of } \\
\text { National Innovation System for } \\
2005-2015\end{array}$ & $\begin{array}{l}\text { Law "About state support of industrial } \\
\text { innovation activities" } \\
\text { Law "About innovation cluster «Park } \\
\text { of innovation technologies" } \\
\text { State Program of Accelerated } \\
\text { Industrial Innovation Development } \\
2010-2014 \\
\text { Conception of Innovation } \\
\text { Development of Kazakhstan until } 2020\end{array}$ & $\begin{array}{l}\text { Amendments to some legal acts on } \\
\text { stimulation of innovation activity } \\
\text { State program of industrial- } \\
\text { Innovation development 2015-2019 }\end{array}$ \\
\hline 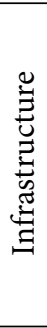 & $\begin{array}{l}\text { Park of information technologies } \\
8 \text { technoparks } \\
1 \text { sectoral design offices }\end{array}$ & $\begin{array}{l}\text { Nazarbayev University } \\
\text { Park of Innovation technologies } \\
8 \text { technoparks } \\
4 \text { sectoral design offices } \\
21 \text { office of commercialization } \\
5 \text { international centers for technology } \\
\text { transfer }\end{array}$ & $\begin{array}{l}\text { Development of intellectual - } \\
\text { innovation clusters } \\
\text { Sales of industrial parks and design } \\
\text { offices to private sector } \\
\text { Creation of innovation workshops, } \\
\text { fab labs, co-working centers } \\
\text { Development of technology transfer } \\
\text { network }\end{array}$ \\
\hline 节 & $\begin{array}{l}\text { Funding of science programs } \\
\text { Project funding } \\
\text { Venture funding }\end{array}$ & $\begin{array}{l}\text { Funding of science programs } \\
\text { Project funding } \\
\text { Venture funding } \\
9 \text { types of innovation grants } \\
\text { Technological business incubation } \\
\text { Targeted technological programs }\end{array}$ & $\begin{array}{l}\text { Funding of science programs } \\
\text { Support for venture funds } \\
\text { Increasing sums of innovation } \\
\text { grants } \\
\text { Support for innovation } \\
\text { infrastructure } \\
\text { Targeted Technological Programs } \\
\text { Online centers of competences } \\
\end{array}$ \\
\hline 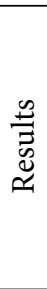 & $\begin{array}{l}\text { In 2009: } \\
\text { Innovation activity of enterprises } \\
-4 \% \text {; } \\
\text { Innovation production in GDP - } \\
0,51 \% ; \\
\text { Kazakhstan in GIC WEF funding } \\
-72\end{array}$ & $\begin{array}{l}\text { Plan for } 2014 \text { : } \\
\text { Innovation activity of enterprises - } \\
10 \%(2013-8 \%) ; \\
\text { Innovation production in GDP - } 1 \% \\
(2013-1,7 \%) ; \\
\text { Kazakhstan in GIC WEF ranking - } \\
48(2013-50)\end{array}$ & $\begin{array}{l}\text { Plan for } 2019 \text { : } \\
\text { Innovation activity of enterprises } \\
-20 \% \text {; } \\
\text { Innovation production in GDP } \\
-2,5 \% \text {; } \\
\text { Kazakhstan in the GIC WEF } \\
\text { ranking }-40\end{array}$ \\
\hline
\end{tabular}

Source: National Agency for Technological Development, Kazakhstan.

been improved, and development institutions, venture capital funds, technology parks, intellectual rights on academic inventions invented at the expense of state budget are given to inventing organizations and other innovation infrastructure have been established (Table 1). However, the majority of the measures undertaken have not paid off.

Several reasons may explain this situation: the frame conditions are not fixed yet, and a superficial approach takes place; there is no understanding that a certain set of factors and conditions forming an environment of innovations is necessary for the emergence and diffusion of innovations.

The economic environment for scientific and technological development remains unfavorable. It is characterized by undeveloped links between the public and higher education sectors and industry, and low innovation activity of enterprises. The interaction of the main innovation develop- ment subjects (state, business, and science) is irregular and does not follow the Triple Helix concept well used in developed countries.

The most difficult thing here is making national businesses aware of the need to become more involved with innovation, to conduct and support research and development. This can be achieved if the interaction of the government, science and business is more active and focused on the Triple Helix (TH) model.

In Kazakhstan, the $\mathrm{TH}$ theory is studied by the Institute of Economics under the Ministry of Education and Science of Kazakhstan.

As for the world research community, Rao \& Xia [1] study university-industry-government R\&D partnership program. Carayannis [2] reveals the importance of the government-industry-university cooperation in growing knowledge economy. Hayashi [3] researches the effect of Japanese $R \& D$ programs on the formation of university-industry- government networks. 
A lot of research is done in the field of university-industry R\&D collaboration. Here are some examples of them:

Etzkowitz H., Leydesdorff L. (2000). The dynamics of innovation: from National Systems and "Mode 2" to a Triple Helix of university-industry-government relations [4].

Kondo, M. (2008). The influence of institutional settings on university-industry R\&D collaboration [5].

Lopez-Femandez, M. C., Serrano-Bedia, A. M., \& Garcia-Piqueres, G. (2008). Exploring determinants of company-university $R \& D$ collaboration in Spain: A contrast between manufacturing and service sectors [6].

Kramer, D. (2008). Universities and industry find roadblocks to $\mathrm{R} \& \mathrm{D}$ partnering [7].

Lacetera, N. (2009). Different missions and commitment power in R\&D organizations: Theory and evidence on industry-university alliances [8].

Hong, J., Heikkinen, J., \& Blomqvist, K. (2010). Culture and knowledge co-creation in R\&D collaboration between MNCs and Chinese universities [9].

Quan, X. (2010). Knowledge diffusion from MNC R\&D labs in developing countries: Evidence from the interaction between MNC R\&D labs and local universities in Beijing [10].
Fiaz, M. (2013). An empirical study of university-industry $R \& D$ collaboration in China: Implications for technology in society [11].

Cunningham, J. A., \& Link, A. N. (2014). Fostering university-industry R\&D collaborations in European Union countries [12].

Lee, K. (2014). University-industry R\&D collaboration in Korea's national innovation system [13].

\section{R\&D\&I performance of Kazakhstan}

Innovation activity of companies in Kazakhstan is very low $-5,7 \%$. According to the National Statistic Agency, the level of innovation activity of companies is the share of companies engaged in innovation activity in the total number of surveyed companies. In local and international interpretation, innovation activity is the activity linked to transformation of ideas into: 1) new or improved products in the market; 2 ) new or improved technological process, used in the practice; 3) new approach to social services.

The main reason of low innovation activity is that the economy of Kazakhstan remains irresponsive to innovations. This is also confirmed by such an indicator as the share of innovative production in GDP. It has been rising during recent years (1.1\% in 2009) and currently makes up $1.64 \%$ of GPD (2013).

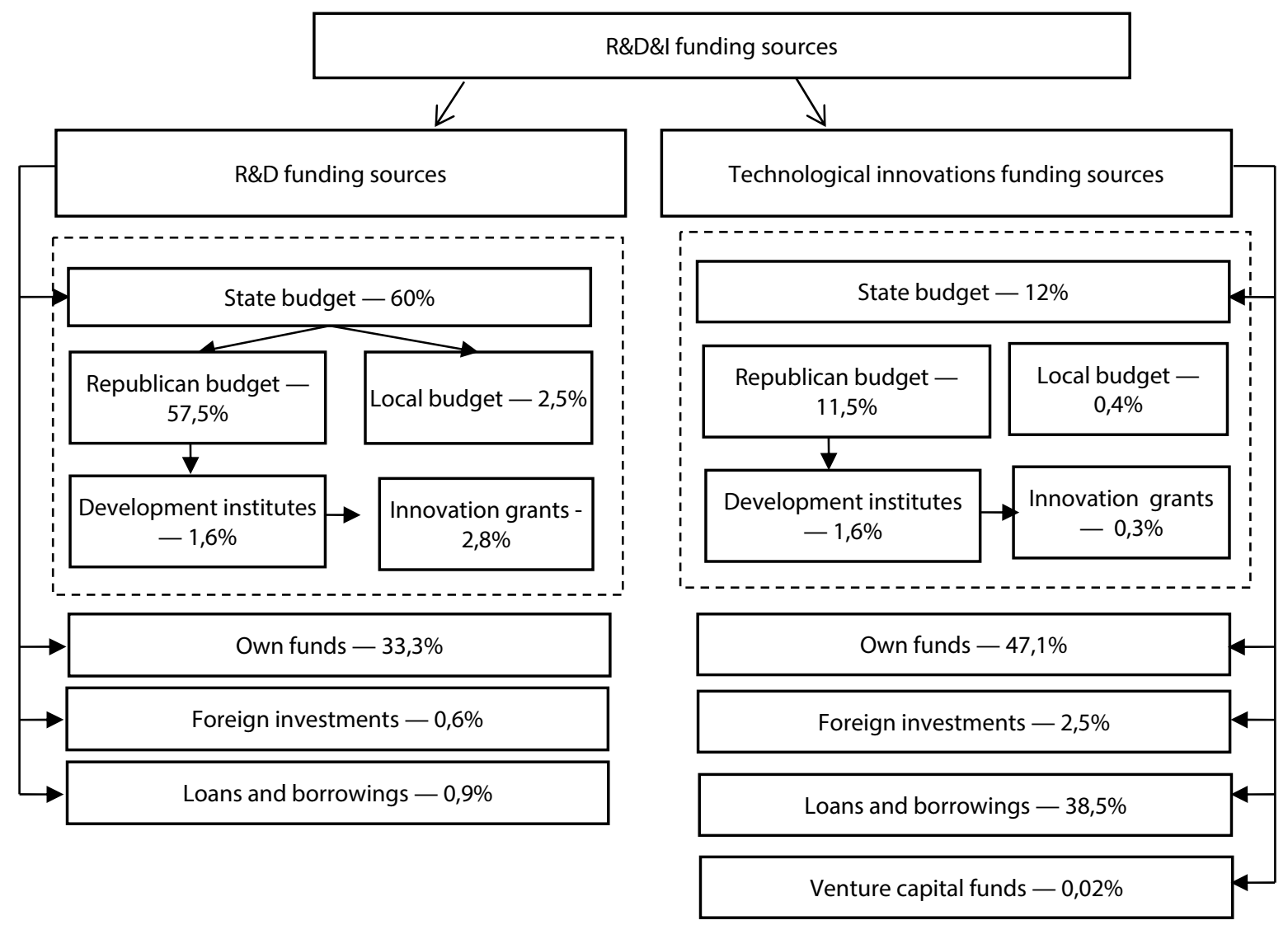

Fig. 1. Sources and structure of funding of science and innovation in the Republic of Kazakhstan in 2013 


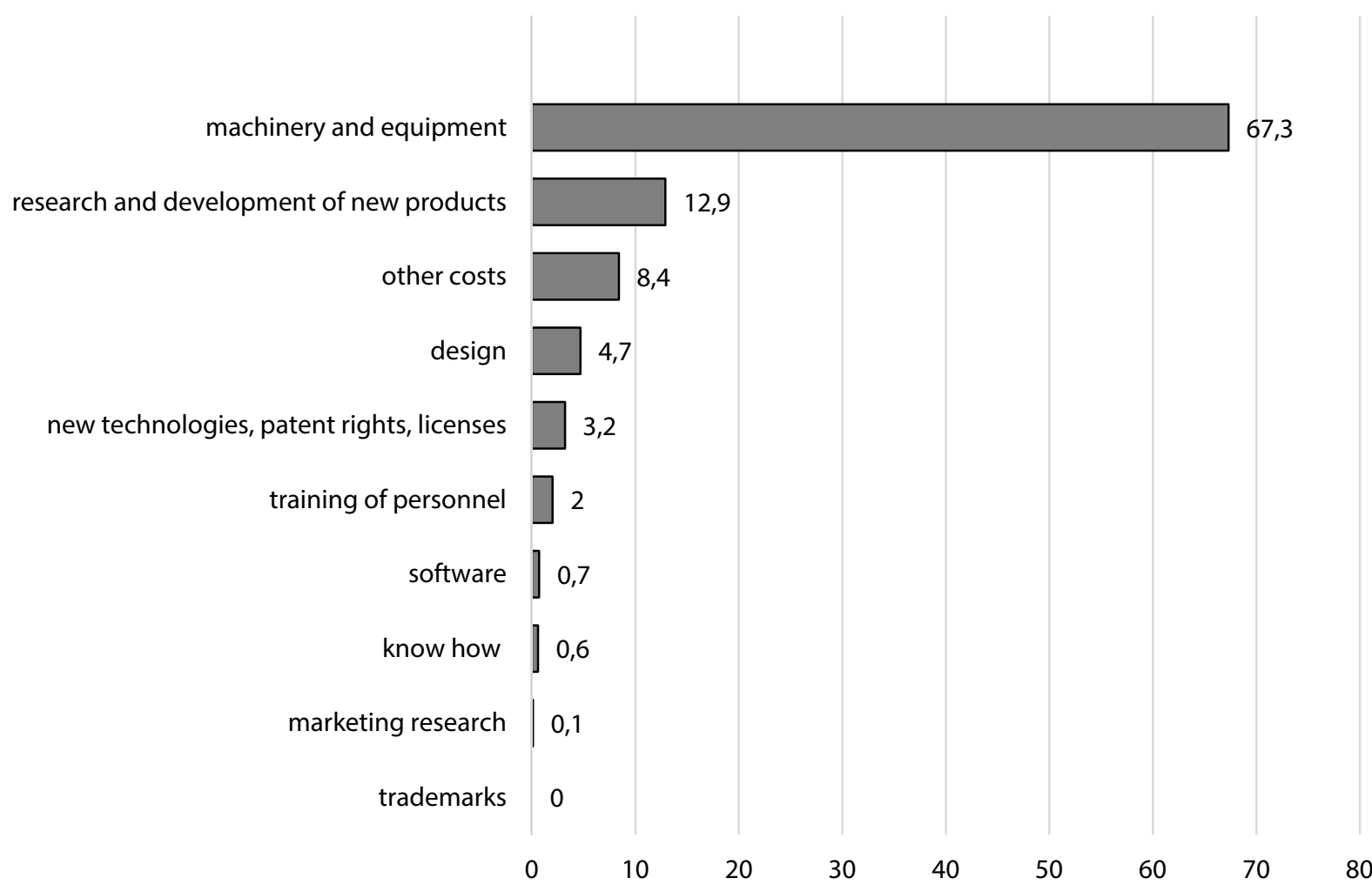

Fig. 2. The structure of costs for technological innovation

The main sources of funding innovations in Kazakhstan are companies' own funds. (Figure 1). This is due to a lack of alternative funding sources. The role of bank loans has considerably increased recently; loans (the second source of innovations funding) are mostly used to purchase innovative equipment. The venture capital concept has not been developed, due to an undeveloped capital market and the absence of national corporations interested in creating internal ventures. Established in 2003, The National Agency for Technological Development (former - National Innovation Fund) was designed to operate as a "Fund of funds". Eleven (five - foreign and six local) venture funds were created under this Fund.

The third most used funding source is state budget funding (12\%). Nevertheless, the state innovation support share, granted by development institutions and through innovation grants, is very small $(1,6 \%)$.

An insignificant share of innovation funding comes from foreign investment (2.5\%), especially if we take into account its relatively high share of overall investment to assets in Kazakhstan: 14 \% in 2012 [14]. This means that foreign capital does not yet have a significant impact on technological development in Kazakhstan.

The technology innovation spending arrangement is imperfect. In particular, the main share of spending is allotted to the purchase of machinery and equipment $-67.3 \%$ while spending on the research and development is $12.9 \%$. The level of expenditure on the purchase of new technologies, especially patents and licenses, remains low (Figure 2). Insufficient attention is paid to staff training. According to expenditures, the issue of training is poorly addressed. These add up to only $2 \%$.

Given the relatively low capacity of the domestic market, it is not possible to expect large-scale growth of innovative production. To expand market opportunities for new products, enterprises need to pay attention to market research, the creation of trademarks and brands, patent protection, etc. Meanwhile, the armory of modern methods of introducing domestic products to market is used insufficiently.

It is worth noting the positive changes to the structure of innovation production. So, while in the period of 2003-2005 the improved products dominated, later a major share started to belong to newly introduced or significantly modified products that require the creation of a more complex system of relationships between innovators, suppliers, consumers.

Consideration of innovation activity of enterprises in Kazakhstan from the viewpoint of opportunities to implement new innovation models, such as the «Triple Helix of innovations» and «open innovation» models, revealed the following: the transfer of new technologies through acquisition of equipment, materials dominates in inno- 


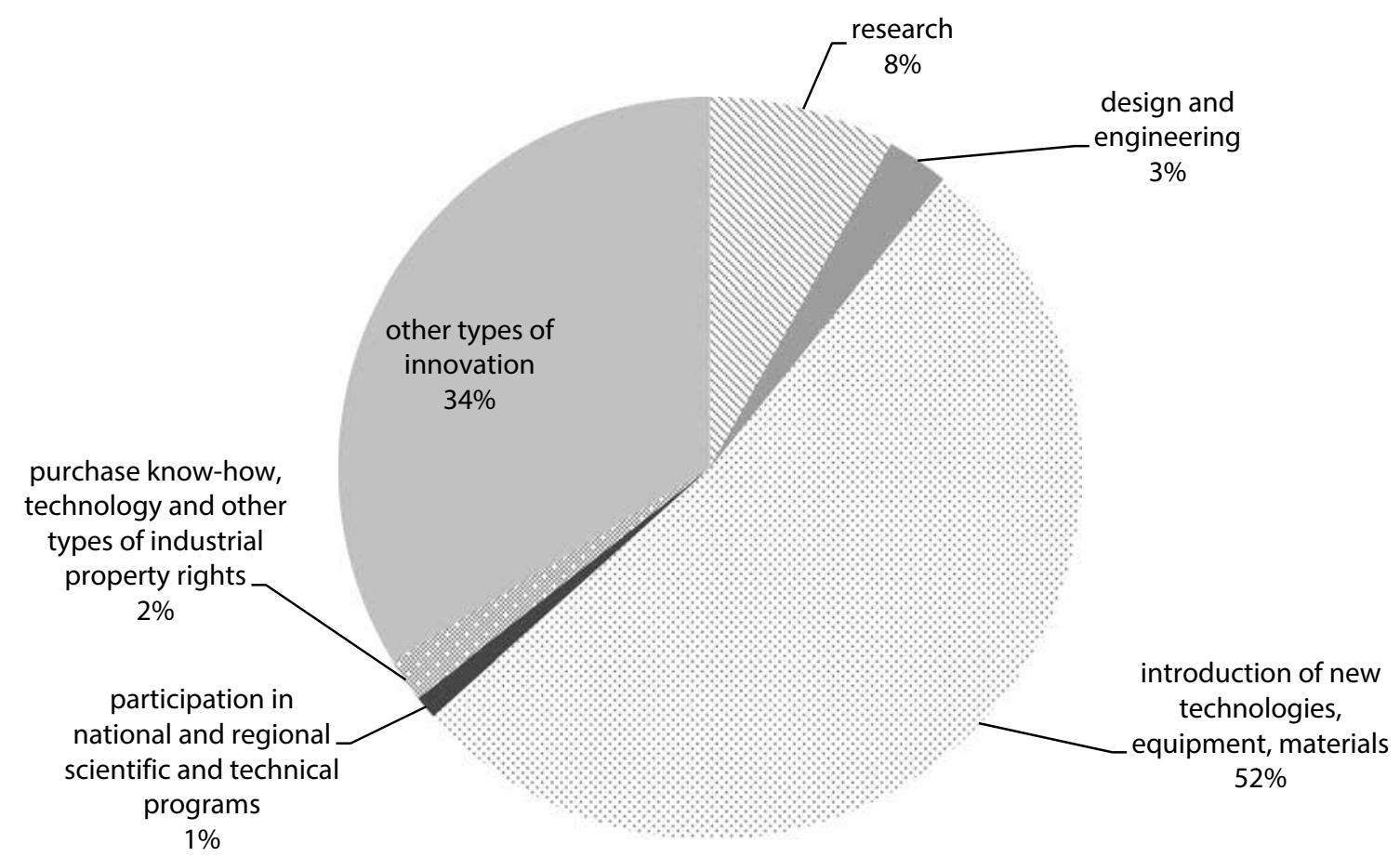

Fig. 3. The main types of innovation activities of enterprises

vation activity $-52 \%$, research holds a relatively high share. However, design activities remain underused (Figure 3).

This indirectly confirms that enterprises tend to use absorption capacity (acquiring technologies/knowledge from outside the country), rather than actual innovation. This type of innovation activity has its limitations. If the scientific capacity is not built on over time, then the adaptive capabilities will go down, and the «Triple Helix» will get deformed.

Kazakh firms also use elements of the «open innovation» model: innovation activities run by enterprises are greatly influenced by: the market actors (customers, competitors, equipment suppliers) $-43 \%$, internal sources (within a company) $-26 \%$, external sources (universities, public and private research institutes, consultants) $11 \%$ and other sources (conferences, trade fairs, exhibitions, scientific journals, technical publications, industrial associations) $-19 \%$ [14].

In Kazakhstan the government is still the main source of $R \& D$ funding, providing up to $60 \%$ of funds for R\&D as opposed to developed countries (Japan - 15,6 \%, USA - 27,7 \%, Germany $27,8 \%$, Korea $-24,8 \%)^{1}$.

The entrepreneurial sector applies to external resources in doing research: $35 \%$ of total $R \& D$ expenditures refers to external expenditures

\footnotetext{
${ }^{1}$ OECD.(2011), MainScienceandTechnologyIndicatorsdatabase http://www.oecd-ilibrary.org/science-and-technology/mainscience-and-technology-indicators/volume-2011/issue1_msti-v2011-1-en-fr.
}

while the other sectors attract just 5-6\% of all resources from the external environment. It seems the entrepreneurial sector attracts mostly personnel from other research organizations.

The sector of higher professional education directs the highest share of its spending for labor payment $-58 \%$ while the public and non-commercial sectors' share is $41-42 \%$. But it is not clear if the higher education sector attracts more personnel or gives higher salaries for doing research.

If to look at the $R \& D$ spending structure we can observe that the entrepreneurial sector spends more for applied research and experimental developments in compare with other sectors (46\% and $36 \%$ respectively). So, it is possibly that the entrepreneurial sector of domestic R\&D is closer to technology commercialization perspectives. The developed countries spend the highest share of R\&D spending for experimental developments, for example, Japan - $60 \%$, USA - $63 \%$, France $44 \%$. Kazakhstan's average share for the experimental developments is still low (Table 2).

The higher professional education, public and non-commercial sectors are likely to move very slowly to technology developments - they are still concentrated in research $(91 \%, 92 \%$ and $95 \%$ of spending respectively).

And it is also interesting that the non-commercial sector spends more (42\%) for basic research than the public sector $(20 \%)$ which traditionally supports basic research.

So, if we classify the sectors by the amount of $\mathrm{R} \& \mathrm{D}$ spending, we can see that the higher edu- 
The share of different types of research in total domestic R\&D spending, 2013

\begin{tabular}{|l|c|c|c|}
\hline \multirow{2}{*}{} & \multicolumn{2}{|c|}{ Domestic Spending for } & Domestic Spending for \\
\cline { 2 - 3 } & Basic research & Applied research & 0,16 \\
\hline Total & 0,30 & 0,54 & 0,08 \\
\hline Public sector & 0,20 & 0,72 & 0,09 \\
\hline Higher professional education sector & 0,46 & 0,45 & 0,36 \\
\hline Entrepreneurial sector & 0,18 & 0,46 & 0,05 \\
\hline Non-commercial sector & 0,42 & 0,53 & \\
\hline
\end{tabular}

Source: Statistic Agency of the Republic of Kazakhstan, 2013/

Table 3

Sources of R\&D funding by sectors of activity, 2013

\begin{tabular}{|l|c|c|c|c|c|}
\hline & \multirow{2}{*}{ Own funding } & \multirow{2}{*}{$\begin{array}{c}\text { Republican } \\
\text { budget }\end{array}$} & including & \multirow{2}{\text{Local}}{$\begin{array}{c}\text { Foreign } \\
\text { investments }\end{array}$} \\
& & Innovation grants & budgets & (n) \\
\hline Total & 0,29 & 0,63 & 0,06 & 0,01 & 0,01 \\
\hline Public sector & 0,11 & 0,82 & 0,06 & 0,01 & 0,01 \\
\hline Higher professional education sector & 0,19 & 0,76 & 0,08 & 0,00 & 0,00 \\
\hline Entrepreneurial sector & 0,62 & 0,28 & 0,05 & 0,01 & 0,00 \\
\hline Non-commercial sector & 0,17 & 0,67 & 0,04 & 0,01 & 0,02 \\
\hline
\end{tabular}

Source: Same as for Table 1.

Table 4

Number of R\&D personnel by sectors of activity in Kazakhstan, 2013

\begin{tabular}{|l|c|c|c|c|c|}
\hline & \multirow{2}{*}{$\begin{array}{c}\text { The number of companies } \\
\text { engaged in R\&D }\end{array}$} & $\begin{array}{c}\text { Number of R\&D } \\
\text { personnel }\end{array}$ & \multicolumn{3}{|c|}{ Including } \\
\cline { 4 - 6 } & 341 & 23712 & 17195 & 3586 & 2931 \\
\hline Total & 78 & 5516 & 3855 & 1042 & 619 \\
\hline Public sector & 112 & 11828 & 9208 & 1345 & 1275 \\
\hline $\begin{array}{l}\text { Higher professional } \\
\text { education sector }\end{array}$ & 110 & 5036 & 3155 & 1028 & 853 \\
\hline Entrepreneurial sector & 41 & 1332 & 977 & 171 & 184 \\
\hline Non-commercial sector & & & & & \\
\hline Share of: & 0,23 & 0,23 & 0,22 & 0,29 & 0,21 \\
\hline Public sector & 0,33 & 0,5 & 0,53 & 0,37 & 0,43 \\
\hline $\begin{array}{l}\text { Higher professional } \\
\text { education sector }\end{array}$ & 0,32 & 0,21 & 0,18 & 0,29 & 0,29 \\
\hline Entrepreneurial sector & 0,12 & 0,06 & 0,06 & 0,05 & 0,06 \\
\hline Non-commercial sector & & & & & \multirow{2}{*}{ technicians } \\
\hline
\end{tabular}

Source: Same as for Table 1.

cation sector spends more for basic research, the public sector - for applied research, and the entrepreneurial sector is more deeply oriented to applied research and experimental developments (Table 3).

The analysis of R\&D funding sources shows that all sectors except the entrepreneurial sector, which R\&D generally is fed by their funds, mostly are working at the expense of the republican budget. It is also evident that there are no links with local budgets and foreign sources. But the entrepreneurial sector is more fed by local budgets as $51 \%$ of total funding from local budgets goes to this sector (Table 3).

The vertical analysis also shows that the public sector and the higher professional education sector are the main consumers of governmental funding while the public sector consumes $57 \%$ of all foreign investments. Also, in 2013 we can observe the dominating of the higher professional education sector in the number of R\&D personnel (Table 4).

In general, innovation chains in Kazakhstan are turned to local partners, and here a bigger role 
is played by scientific organizations, equipment suppliers, and consumers.

Kazakhstani companies are more oriented on innovations from foreign countries, and partner companies and suppliers play the main role. However, this activity is focused mainly on local markets, as foreign consumers have no influence on innovative solutions practically.

Thus, Kazakhstani business uses open innovation model on a limited scale, this restricts the transfer of innovations to foreign markets, participation in global production chains and international research networks.

Given the low rates of industrial innovation activity, public research organizations and development institutions are important partners. This suggests that there already are some forms of interaction and preconditions for the development of the domestic «Triple Helix» model.

\section{Preconditions for development of the Triple Helix model in Kazakhstan innovation development}

According to the Triple Helix model, the main actors of innovation development are science, business, and government. At different stages of innovation development their roles change. The market plays an important role in encouraging innovation activity, but it is not always able to provide dynamic innovation development. The government plays a very specific role - it develops a long-term strategy of innovation and socio-economic development on one hand and realizes activities for science support and business incentives on the other hand.

Innovation policy has not developed yet in a complete form. Overall, despite the claim that innovation development is a priority in Kazakhstan, there are some outstanding issues:

- elements of the innovation system related to the practical implementation of innovation, such as small innovative companies, innovation centers, innovation clusters, are not well developed and the existing ones integrate poorly with a unified development strategy;

- a number of Special Economic Zones (SEZ) were created. However, only one of them (the Park of innovation technologies) supports innovation, and only one Technopark was created in the high- tech sector (Nuclear Technologies Park);

- there is a program of the National Agency for Technology Development (NATD) which supports innovation start-ups, but participation in it is very restricted, and there are not any innovation business support programs;
- no tax incentives for the innovation business, customs tariffs do not stimulate import of advanced technological equipment;

- innovation policy is not yet systematic, it does not combine activities in science and technology, education, industrial sectors and regional initiatives.

Our own scientific capacity is not able to provide development of innovation processes, primarily due to weak technological links. Research institutes and universities do not have stable links with industries. Corporate science is underdeveloped. Scientific research results are not in demand in the economy in general and are hardly commercialized. A business, in general, is not inclined to innovate. There are several reasons for this.

Firstly, business is concentrated in the commodity sector, which demonstrates a reduced tendency to innovate. There are not any large hightech corporations.

Secondly, there is little motivation for business. Large-scale national business is used to windfalls generated by the commodity sector and a quick pay off of the investments in the trade and finance sector.

Thirdly, there is a gap between science and business, old ties between academia and industry were destroyed after the collapse of the Soviet Union and new ones have not yet been established.

Fourthly, domestic entrepreneurs do not widely use «civilized» business models.

In order to create a premise for Triple Helix, it is reasonable to follow these directions:

1. Innovation policy in the country is characterized by incentives for science development in the public and higher education sectors. Industrial research and development are not yet the objects of innovation policy. Therefore, promotion of research and development in industrial enterprises is of particular importance. As for now, it is the weakest link of the emerging innovation system of the country.

2 . The increase of business expenditures on research and development. To achieve this, there is a need for direct financial support from the state to be complemented by strong tax incentives and investment benefits. It is necessary to expand the list of taxation breaks for science in Kazakhstan.

3. It is necessary to provide preferential rates or exemption of import duties in the customs rules in order to facilitate access to the latest technology, and scientific equipment. This is specifically necessary because scientific instruments, laboratory equipment for scientific research in higher and secondary educational institutions are not produced in Kazakhstan. 
4. It is important to expand the practice of partnership between public and private sectors, to use the mechanisms of research and development co-funding by the government and business. For these purposes, in particular, it is necessary to make wider use of development institutions' resources (Kazakhstan Development Bank, Investment Fund, NATD, etc.). As of today, they account for only $0.7 \%$ of total scientific expenditures.

In general, it is crucial to build up the "critical mass" of innovatively active enterprises. Therefore, the main task of innovation policy is to develop business innovation incentives:

The urge to deploy research should come from large national companies and foreign investors, which in turn, should be encouraged by the state through tax and other incentives.

To expand the sources of science and innovation funding, in particular, through redistribution of rent generated by the commodity sector from the use of natural resources. Now resource extractors have an obligation to allow $1 \%$ of the total annual revenue to research and development. According to the Ministry of Industry and New Technologies, the amount of $R \& D$ funding by subsoil users will increase up to 250 million USD. It is important to enhance this approach, in particular, to consider establishing a Technological Development Fund (TDF), which could be sourced by fixed deductions of, for example, $0.5 \%$ of commodity companies' corporate income. In Kazakhstan, there are only two funds - Science Fund and NATD.

Bridge the gap between the research and entrepreneurial spheres through the creation of technology parks and venture capital funds. A comprehensive approach based on creating of innovation clusters is more useful.

\section{Development of clusters in Kazakhstan}

In the 2000s, the Triple Helix model started to be introduced into economies of developed countries as a base of regional clusters and innovations generation base ${ }^{1}$. The use of the cluster policy by many countries received the definition of "cluster initiative". There are over 500 cluster initiatives in the world. The "cluster initiative» of the Kazakhstan government has been functioning in Kazakhstan since 2005, providing the creation and development of pilot clusters in seven directions: tourism, the food industry, oil and gas mechanical engineering, the textile industry, transport

\footnotetext{
${ }^{1}$ OECD. (2007). Competitive Regional Clusters: National Policy Approaches, 2007. http://www.oecd.org/gov/regional-policy/ competitiveregionalclustersnationalpolicyapproaches.htm .
}

and logistics services, metallurgy and production of construction materials. ${ }^{2}$ There is a search for other possibilities to emerge clusters.

To avoid failures in clusterization, it is important to understand that clusters are a based on the network model of the economy. As it was noted above, the modern economy has a network character, turning into the economy not of separate enterprises, but of their networks. The advantage of a network is that its productivity increases not linearly when scales of the network grow, but each node receives additional benefits from a simple increase in the number of knots.

Each cluster is a network where cooperation between legally independent companies brings benefit to each of them in the form of agglomeration effects (benefits of a real concentration) and effects of cooperation. An important feature of a cluster is that their participants are not only in cooperating, but also competing with each other. The participants in the cluster, while uniting efforts on the creation of one new product, continue to compete in others.

If we look from this point of view, some simplified understanding of the essence of clusters in Kazakhstan practice should be noted. In our opinion, what is underestimated is that the cluster concept is based on the innovation factor. There is practically no hi-tech direction mentioned in the «cluster initiative». It has not been taken into account that firms competing with each other unite into clusters, and this demands the formation of a special entrepreneurial environment which is based on trust between competitors.

In the context of cluster policy development in Kazakhstan, it is important to understand that the cluster - network principle of business organization cannot be forced. Regardless of whether the necessary conditions are there or not. The most well-known innovation cluster in the world today, Silicon Valley, was created not by «order from above», but upon initiative from below, on the basis of horizontal cooperation.

It does not mean that it isn't necessary to create institutional prerequisites for the network development of companies. The experience of a number of countries of Northern Europe and South East Asia show that not only market forces are behind the formation of innovation clusters and that progress in their development is connected with the mechanism of the Triple Helix. [15] Stability and successful functioning of clusters are based on the

\footnotetext{
${ }^{2}$ About approving the plans for establishing and developing pilot clusters in priority sectors of Kazakhstan. Decree of the Government of the Republic of Kazakhstan dated by 25 of June, 2005, \# 633
} 
interaction of at least three standard participants of cooperation: sciences, business, and government. The clusters' innovative effect is defined by their network building.

In our opinion, it should be noted that there are a lot of constraining factors when estimating possibilities of cluster development in Kazakhstan. Firstly, the situation with institutional and social factors is adverse. In the country an entrepreneurial culture has not yet taken root, the competition is not always conscientious, as a whole, the entrepreneurial environment does not have an atmosphere of trust between economic agents themselves and government institutes. A constraining factor is a low psychological readiness for cooperation between the enterprises of various branches and regions; and the poor development of chambers of commerce and industrial associations.

Secondly, inherited from the previous stage of development the economy of Kazakhstan has a one-sided, fragmentary character, it has no reproduction integrity, the majority of enterprises are not really connected with each other technologically. It means that it is difficult to build technological chains within the country as a whole, let alone in certain regions. They often stretch to neighboring countries.

Thirdly, for the time being, the majority of regions of Kazakhstan are characterized by a limited set of high technology industrial branches, a sharp shortage of higher education and research institutes that generate innovations. Next year it is hard to expect the formation of a lot of fully functional innovation clusters [16].

Considering this, Astana and Almaty have the greatest prospects for cluster development. In particular, it is possible to expect the formation of medical and biotechnological clusters in Astana and scientific and educational clusters in Almaty. ${ }^{1}$

The first clusters have already been developing on the basis of Nazarbayev University and the Park of innovative technologies in Almaty. There are best prerequisites for the development of «Triple Helix» in Kazakhstan.

Thus, there is a question, which innovation models to follow. Henry Etzkowitz showed three possible options:

- establishing scientific parks jointly with multinational corporations;

- endogenous model, when on the base of university research groups of «multi-purpose know-

\footnotetext{
1 The concept of perspective national clusters formation in Kazakhstan until 2020.Decree of the Government of the Republic of Kazakhstan dated by 11 October, 2013, \# 1092
}

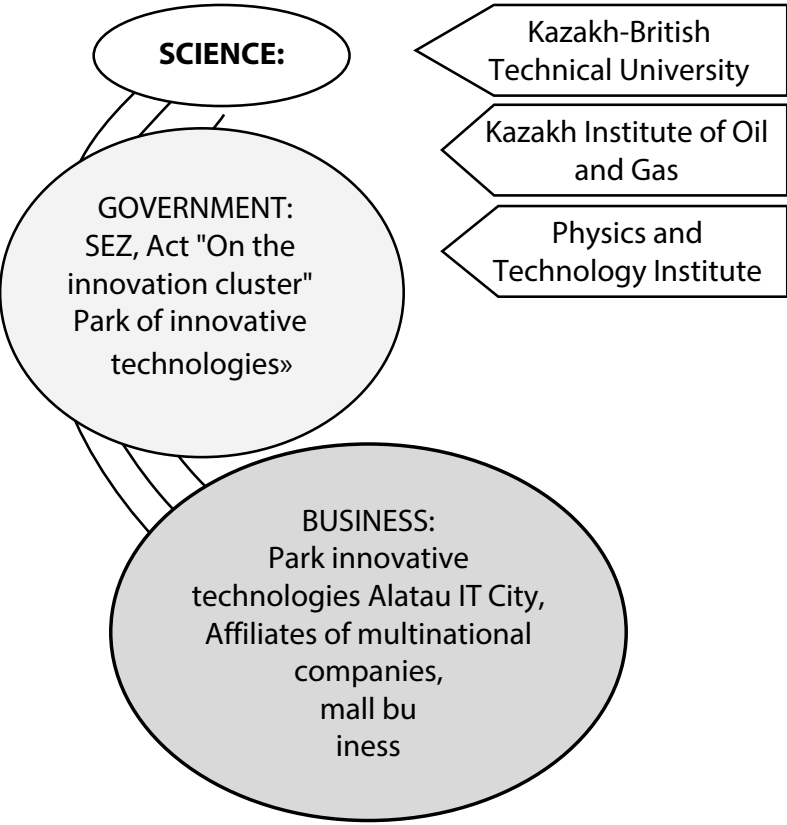

Fig. 4. «Triple Helix» Model on the basis of the SEZ "Park of innovative technologies"

ledge» consisting of theorists and practitioners working closely together, generating inventions and creating spin-offs and new products.

A hybrid model that unites the exogenous approach of foreign direct investments and the endogenous approach when the incubation of the knowledge-intensive business and transfer of technologies based on local sources [17].

Currently, for Kazakhstan it is possible to speak about two models: the first and third. The second model is excluded because local universities' ecosystems are not adapted for generating innovations, and there are no links between theorists and practitioners. The first model can be implemented on the base of Park of innovative technologies (Figure 4).

The park functions in the form of the special economic zone that creates conditions for the involvement of branches of the multinational corporation. However, contrary to its name, it is not a scientific park, not technological, but rather industrial park as there are no scientific links, no educational structures. But in near future, placement of Kazakh-British University, and also the Kazakh Institute of oil and gas is planned for the park. It is possible to attract potential capacities of the Institute of Nuclear Physics and Physics and Technology Institute located on this territory.

The third model can be realized on the basis of Nazarbayev University in Astana (Figure 5).

The main advantage of that model is the Nazarbayev University developed by an analogy of western universities. It is planned to strengthen its scientific base, presented now by the Center for 


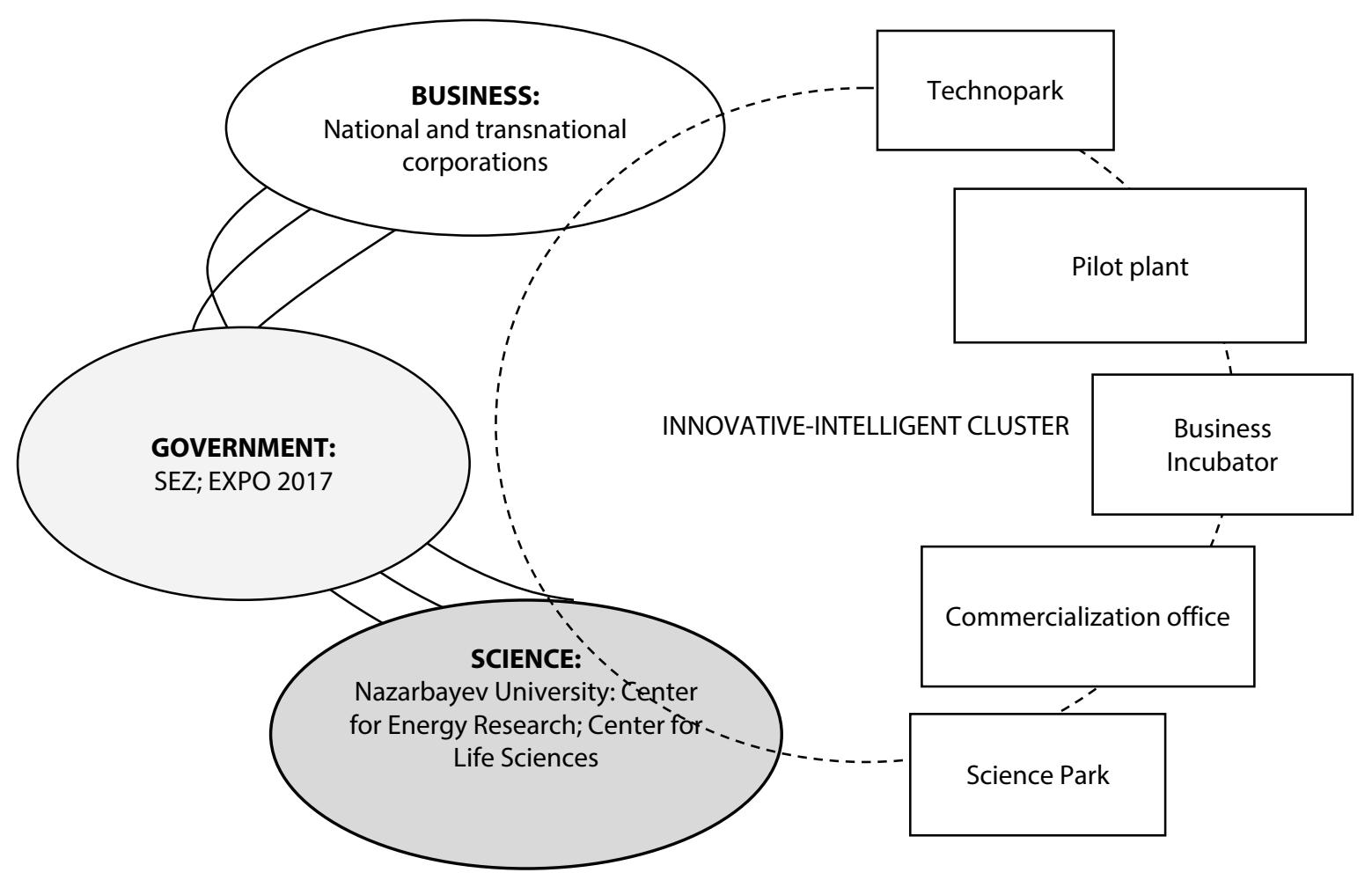

Fig. 5. Hybrid model «Triple Helix» on the basis of Nazarbayev University

life sciences, the Center for power research and the Interdisciplinary Center. It is planned to concentrate scientific and technical centers of large-scale national business there. Thus, the largest national companies KAZATOMPROM and KAZKOSMOS have already placed their research centers on solar power and space technologies at the University.

The introduction of special economic zones will contribute to the development of the third model. In this case, it will be possible to attract the interest from large multinational corporations to create research laboratories there. Thus, it will be possible to speak about «Triple Helix» with the participation of international business.

For the development of clusters in Kazakhstan, it is desirable to use such a way, as integration into global cluster networks. It is necessary to be guided by the phenomenon of network economy as widespread practice of cooperation in which research and development can be placed in one country, production in another, sales in a third, and the management company is based in a fourth. Therefore, the open declaration of a course on the broad import of technologies is obviously important in Kazakhstan.

As the world practice shows, there are different options for the innovation cluster creation; the evolutionary way by method from "bottom" (due to action of market forces), the way of designing by method from "up" (due to formation of special programs).
Obviously, considering the immaturity of our market environment, the first way will demand too much time for Kazakhstan. The second way as shown by the unsuccessful experiment of «Kazakhstan cluster initiative» is also inexpedient. Therefore, the third option based on the combination of market forces and creative forces of economic policy is preferable.

Thus, it is necessary to use foreign experience at which various specialized state agencies become participants of clusters. They are engaged in tracking new cluster cores, helping participants of the cluster to establish partner relations, and regulating the system of network interactions in Triple helix model. In Kazakhstan, the function of such an agency could be assigned to the Kazakhstan center of a public-private partnership or the National Agency of Technological Development or to establish the new independent agency.

\section{Conclusion}

In Kazakhstan, the interaction of the government, science and business is not sustainable yet. In most cases, it is not equal, close to vertical subordination with a dominant position of the government and lack of feedback. Business and science do not build relationships directly, but rather indirectly, via the government. Both theory and practice underestimate the complex nature of innovation, which leads to unilateral, technocratic 
approach to selecting methods of creation of favorable conditions for the interaction of the main innovation subjects. In this context, innovation policy should pay more attention not only to science, as now, but also to businesses, which must play a central role in the innovation process.

The emerging national innovation model system is fragmented. There are elements inherited from the past, which include a relatively high level of education and strong positions of many areas of science. The new elements (objects of innovation infrastructure, new universities, and clusters) either act as pilot projects or have not gained critical mass. It is necessary to ensure that development of the innovation system is provided not only by the government, as it is mostly provided now, but also by better involvement of private business, the part of which is still extremely restricted.

Ensuring a conducive institutional environment for innovation in Kazakhstan requires more precise and direct innovation policy, the organic cooperation of state and market institutions under a single mechanism providing improving competitive capacity through innovation factors.

International experience demonstrates that there is a policy aimed at the development of science, technology and innovation, and macroeconomic policies aimed at creating framework conditions for innovation (macroeconomic stability, taxation, competition, openness, intellectual property rights, etc.). Keeping this in mind, it is advisable to develop science, technology and innovation policies simultaneously with policies aimed at improving the framework conditions.

Greater attention should be given to new forms of innovation activity forms: clusters, technology parks, industrial zones, etc. It must be considered that not only real assets are important, but also institutional and social interaction of all participants and the atmosphere of mutual trust.

\section{References}

1. Rao, M., \& Xia, Q. (1997). IOMCS project - A University/Industry/Government R\&D partnership program. International Journal of Engineering Education, 13(4), 275-284.

2. Carayannis, E. G., \& Alexander, J. (1999). Winning by cooperating in strategic government- university-industry R\&D partnerships: The power of complex, dynamic knowledge networks. Journal of Technology Transfer, 24(2-3), 197-210.

3. Hayashi, T. (2003). Effect of R\&D programmes on the formation of university-industry-government networks: Comparative analysis of Japanese R\&D programmes. Research Policy, 32(8), 1421-1442.

4. Etzkowitz H., \& Leydesdorff, L. (2000). The dynamics of innovation: from National Systems and "Mode 2" to a Triple Helix of university-industry-government relations. Research Policy, 29(2), 109-123.

5. Kondo, M. (2008). The influence of institutional settings on university-industry R\&D collaboration. Proceedings of the 4th IEEE International Conference on Management of Innovation and Technology, 110-115.

6. Lopez-Femandez, M. C., Serrano-Bedia, A. M., \& Garcia-Piqueres, G. (2008). Exploring determinants of company-university R\&D collaboration in Spain: A contrast between manufacturing and service sectors. Journal of Manufacturing Technology Management, 19(3), 361-373.

7. Kramer, D. (2008). Universities and industry find roadblocks to R\&D partnering. Physics Today, 61(5), 20-22.

8. Lacetera, N. (2009). Different missions and commitment power in R\&D organizations: Theory and evidence on industry-university alliances. Organization Science, 20(3), 565-582.

9. Hong, J., Heikkinen, J., \& Blomqvist, K. (2010). Culture and knowledge co-creation in R\&D collaboration between MNCs and Chinese universities. Knowledge and Process Management, 17(2), 62-73.

10. Quan, X. (2010). Knowledge diffusion from MNC R\&D labs in developing countries: Evidence from interaction between MNC R\&D labs and local universities in Beijing. International Journal of Technology Management, 51(2-4), 364-386.

11. Fiaz, M. (2013). An empirical study of university-industry R\&D collaboration in China: Implications for technology in society. Technology in Society, 35(3), 191-202

12. Cunningham, J. A., \& Link, A. N. (2014, May 7). Fostering university-industry R\&D collaborations in European Union countries. International Entrepreneurship and Management Journal, 1-12.

13. Lee, K. (2014). University-industry R\&D collaboration in Korea's national innovation system. Technology and Society, 19(1), 1-25.

14. Agentstvo respubliki Kazakhstan po statistike [Statistic Agency of the Republic of Kazakhstan]. (2014). Investitsii $i$ stroitelnaya deyatelnost $v$ respublike Kazakhstan 2009-2013 [Investment and construction activity in the Republic of Kazakhstan in 2009-2013]. Astana: Statistic Agency of the Republic of Kazakhstan, 50.

15. Smorodinskaya, N. (2011). Troynaya spiral kak novaya matritsa ekonomicheskikh system [Triple helix as a new matrix of economy systems]. Innovatsii [Inovatsions], 4, 38-43. Dnishev, F., \& Alzhanova, F. (2013). Development of innovations and technologies in terms of globalization: the world experience and Kazakhstan. Published by Institute of Economics under the Ministry of education and Science, Almaty, 62.

16. Etzkowitz, H. (2011). Troyanaya spiral. Universitety - predpriyatiya - gosudarstvo. Innovatsii v deystvii [A triple helix. Universities- enterprises-government. Innovation in action]. English translation under edition of A.F. Uvarov. Tomsk, Mass.: TUSUR Press. 


\section{Information about the authors}

Dnishev Farkhat Musayevich (Almaty, Kazakhstan) - Doctor of Economics, Professor, Chief Researcher, Institute of Economics of the Committee of Science of the Ministry of Education and Science of the Republic of Kazakhstan (29, Kurmangazy St., 050010 Almaty, Kazakhstan; e-mail: dfm0704@gmail.com).

Alzhanova Farida Gazizovna (Almaty, Kazakhstan) - Doctor of Economics, Head of the Center for Innovative and Technological Development, Institute of Economics of the Committee of Science of the Ministry of Education and Science of the Republic of Kazakhstan (29, Kurmangazy St., 050010 Almaty, Kazakhstan; e-mail: farida.alzhanova@gmail.com).

Alibekova Gulnaz Zhanatovna (Almaty, Kazakhstan) - PhD Student, New Economic University named after T. Ryskulov (55, Zhandosov st., 050035 Almaty, Kazakhstan; e-mail: g_alibekova@mail.ru). 